Maurice A. Deane School of Law at Hofstra University

Scholarly Commons at Hofstra Law

Hofstra Law Faculty Scholarship

1977

\title{
Prior Restraints on Freedom of Expression by Defendants and Defense Attorneys: Ratio Decidendi v. Obiter Dictum
}

Monroe H. Freedman

Maurice A. Deane School of Law at Hofstra University

Janet Starwood

Follow this and additional works at: https://scholarlycommons.law.hofstra.edu/faculty_scholarship

Part of the First Amendment Commons

\section{Recommended Citation}

Monroe H. Freedman and Janet Starwood, Prior Restraints on Freedom of Expression by Defendants and Defense Attorneys: Ratio Decidendi v. Obiter Dictum, 29 Stan. L. Rev. 607 (1977)

Available at: https://scholarlycommons.law.hofstra.edu/faculty_scholarship/9

This Article is brought to you for free and open access by Scholarly Commons at Hofstra Law. It has been accepted for inclusion in Hofstra Law Faculty Scholarship by an authorized administrator of Scholarly Commons at Hofstra Law. For more information, please contact lawlas@hofstra.edu. 


\title{
Prior Restraints on Freedom of Expression by Defendants and Defense Attorneys:
}

Ratio Decidendi v. Obiter Dictum

\author{
Monroe H. Freedman* \\ Janet Starwood $\dagger$
}

Nebraska Press Association v. Stuart ${ }^{1}$ presents the Supreme Court's most strenuous disapproval of prior restraints on the press to date. Despite its concern for the first amendment rights of the press, however, the Court showed no such solicitude for the free speech rights of defendants and their attorneys. Instead, the two major opinions ${ }^{2}$ in Nebraska Press Association both contain unsupported, conclusory language suggesting that the special protection afforded the press might somehow be inapplicable to restraints against defendants and defense attorneys. ${ }^{3}$ The implication is that in order to secure their rights to fair trials defendants may have to sacrifice their first amendment rights in the process.

That conclusion involves the assumption that a defendant's exercise of free speech is capable of denying the state a fair trial. Even when the defendant has been the object of pervasive adverse publicity, however, the Supreme Court has recognized that reversal of a conviction on the ground that a fair trial has been denied is rarely required. ${ }^{4}$ Accordingly, a situation in which a defendant could generate publicity sufficient to prejudice the case against the prosecution scarcely can be imagined.

More importantly, fears of defense-generated publicity ignore the fundamental purpose of many of the important constitutional guarantees: protecting the individual from the state, not the reverse. The sixth amendment is concerned explicitly with the fair trial rights of "the accused," and the fifth and fourteenth amendment rights to due process are

*A.B. 1951, LL.B. 1954, LL.M. I956, Harvard University. Dean and Professor of Law, Hofstra University Law School.

†A.B. 1975, Cornell University; J.D. 1978, Hofstra University.

I. 96 S. Ct. 2791 ( 1976 ).

2. Chief Justice Burger's opinion for the majority was joined by Justices White, Blackmun, Powell, and Rehnquist. Justice Brennan's concurring opinion, the most extensive of the separate opinions, was joined by Justices Stewart and Marshall.

3. $96 \mathrm{~S}$. Ct. at $2800 ;$ id. at $2823 \mathrm{n.27}$ (Brennan, J., concurring).

4. Id. at 2800 . 
secured to "any person." Obviously, the Framers of the Constitution were well aware that it is people who require protection against the potentially oppressive power of governments and not the other way around.

That truism would not need to be stated but for the fact that judges and legislators occasionally manage to get it backwards. In Chicago Council of Lawyers. $v$. Bauer, for example, Judge Swygert did just that, combining a good deal of sense with an almost equal amount of nonsense in allowing restraints on defendants and their counsel in limited circumstances. ${ }^{5}$ Judge Swygert acknowledged that "[ $\mathrm{t}]$ he Sixth Amendment speaks only of the right of an accused and the Fifth Amendment only of the right of persons and not of the Government." 6 By a neat sleight of pen, however, he equated the sixth amendment more broadly with the "integrity of our system of justice,"7 and concluded that "public justice is no less important than an accused's right to a fair trial."

Because our society elevates certain aspects of justice to constitutional status, however, Judge Swygert's conclusion is unquestionably wrong. Public justice is less important than an accused's right to a fair trial, precisely because " $[t]$ he Sixth Amendment speaks only of the right of an accused and the Fifth Amendment only of the right of persons and not of the Government." 9

Unlike Judge Swygert, the Supreme Court in Nebraska Press Association did not have the benefit of adversarial presentation regarding the first amendment rights of the accused. ${ }^{10}$ Unfortunately, the opinions in that case contain obiter dicta supporting Judge Swygert's conclusion that

5. 522 F.2d 242, 249 (7th Cir. I975), cert. denied, 96 S. Ct. 3201 (1976).

6. Id. at 250 .

7. Id. "The [Reardon] Committee's research indicates that, although potentially prejudicial disclosures by lawyers participating in a criminal case are relatively infrequent, they do occur and have on many occasions caused considerable difficulty. Moreover, they are particularly likely to occur in cases that arouse substantial public interest, and in these cases it is not unusual for both sides to become active in courting public favor through the press." Id. at 250 n.6, citing ABA Project on Minimum Standards for Criminal Justice, Advisory Comm. on Fair Trial and Free Press, Standards Relating to Fair Trial and Free Press (Approved Draft I968).

8. 522 F.2d at 250. A staff report of the Senate Subcommittee on Constitutional Rights also confused the Framers' concern over individual rights for a prosecutors' Bill of Rights. The staff report derived the non sequitur that "especially since the Constitution secures so many rights for the protection of the defendant," the state has a "right" to a "judicial process untainted by prejudice against the prosecution." Free Press-Fair Trial: A Staff REPORT OF The SUbCOMm. ON CONStitutional Rights of the Senate Judiciary Comm., 94th Cong., 2d Sess. 13 (1976). On the contrary, the clear implication of the Constitution is that the accused-not the government-needs and deserves that special, superior degree of protection against prejudice.

9. 522 F.2d at 250.

IO. Erwin Charles Simants, the accused, intervened in this case but did nor make this argument. See Brief for Respondent-Intervenor, Erwin Charles Simants, Nebraska Press Ass'n v. Stuart, 96 S. Ct. 279 I (1976). 
freedom of speech for the accused may be denied in the name of assuring a fair trial for the state. That result would be directly contrary to the sound reasoning of Nebraska Press Association itself in reaching its conclusion that the press may not be gagged in the interest of a fair trial.

\section{Nebraska Press Association v. Stuart: Sound HoLdING BUT INCONSISTENT DICTA}

\section{A. The Holding}

Within the unequivocal protection of freedom of expression guaranteed by the first amendment, the Supreme Court has found an even greater or "special" protection against prior restraints. ${ }^{11}$ Indeed, in New York Times Co. v. United States 12 "every member of the Court, tacitly or explicitly, accepted the . . . condemnation of prior restraint as presumptively unconstitutional,"13 and in Nebraska Press Association the Supreme Court reaffirmed that "the barriers to prior restraint remain high and the presumption against its use continues intact."14

However, the Court in Nebraska Press Association divided on the question of just how high those barriers should be. The opinion by Chief Justice Burger, with four justices concurring, reiterated "that the guarantees of freedom of expression are not an absolute prohibition under all circumstances . . . ${ }^{15}$ Yet Justices Brennan, Stewart and Marshall were prepared to hold that prior restraints on freedom of the press to report on pending litigation are never constitutionally permissible. ${ }^{16}$ In addition, Justice White expressed "grave doubt" whether such orders would ever be justifiable, ${ }^{17}$ and Justice Stevens indicated that he "may well accept [Justice Brennan's] ultimate conclusion." ${ }^{18}$ Apparently at least five members of the Court ultimately may declare that all prior restraints on press coverage of trials are constitutionally invalid, ${ }^{19}$ even though a majority of the Court did not choose to go that far in Nebraska Press Association.

II. $96 \mathrm{~S}$. Ct. at 280 .

I2. 403 U.S. 713 (1971).

13. Pittsburgh Press Co. v. Pittsburgh Comm'n on Human Relations, 413 U.S. 376, 396 (1973) (Burger, C.J., dissenting), quoted in Nebraska Press Ass'n v. Stuart, 96 S. Ct. 279I, 2802 (1976).

14. $96 \mathrm{~S}$. Ct. at 2808 .

15. Id.

I6. Id. at 2809, 2819 (Brennan, J., concurring).

17. Id. at 2808 (White, J., concurring). Despite his doubts about the validity of such orders, Justice White concurred in the narrower holding because " $[t]$ echnically there is no need to go farther than the Court does to dispose of this case . . . ." Id.

18. Id. at 2830 (Stevens, J., concurring). Justice Stevens preferred not to answer the broader question without further argument. Id.

19. In addition, Justice Powell wrote a short concurrence "to emphasize the unique burden" 
Certainly some commentators will find that exercise in judicial restraint commendable ${ }^{20}$ despite the fact that the resulting doubt and confusion may have a chilling effect upon the first amendment and, as Justice Brennan's concurring opinion indicated, the issues have been thoroughly presented to the Court more than once in the past. ${ }^{21}$

\section{B. The Dicta}

Unfortunately; the Court failed to show that same judicial restraint in its obiter dicta regarding the propriety of prior restraints against freedom of expression by defendants and their counsel. As explicitly recognized in Chief Justice Burger's opinion, such issues were not presented to the Court. ${ }^{22}$ Nevertheless, the opinions of both the Chief Justice and Justice Brennan suggest that, among the less restrictive alternatives available for dealing with pretrial publicity, courts may choose prior restraints against defendants and their counsel. ${ }^{23}$

Those dicta derive principally from Sheppard $v$. Maxwell, ${ }^{24}$ where the Supreme Court said:

The courts must take such steps by rule and regulation that will protect their processes from prejudicial outside interferences. Neither prosecutors, counsel for defense, the accused, witnesses, court staff nor enforcement officers coming under the jurisdiction of the court should be permitted to frustrate its function. Collaboration between counsel and the press as to information affecting the fairness of a criminal trial is not only subject to regulation, but is highly censurable and worthy of disciplinary measures. ${ }^{25}$

The Sheppard Court also commented that the trial judge "might well have proscribed extrajudicial statements by any lawyer, party, witness, or court official which divulged prejudicial matters . . . ."26

Significantly, the references in Sheppard $v$. Maxwell to gagging the defendant and defense counsel went far beyond the appropriate scope of that opinion. The issue posed in Sheppard arose out of the "deluge" of "inherently prejudicial publicity which saturated the community,"

upon a party who seeks to justify a prior restraint. In doing so, Justice Powell explicated his standard in such a way as to approach an absolute bar to prior restraints. Id. at 2808 .

20. We are not among the commentators who applaud the majority's restraint. Rather, we join Justice Brennan in calling for complete prohibition of prior restraints against the press and urge that the prohibition be extended to protect the first amendment rights of defendants and their attorneys.

2I. E.g., Sheppard v. Maxwell, 384 U.S. 333 (1966); Estes v. Texas, 38 I U.S. 532 (1965); Irvin v. Dowd, 366 U.S. 717 (196r).

22. $96 \mathrm{~S}$. Ct. at 2805 n.8.

23. Id. at $2800 ;$ id. at 2823 n. 27 (Brennan, J., concurring).

24. 384 U.S. 333 (1966).

25. $I d$. at $3 \sigma_{3}$ (emphasis added).

26. Id. at 361 . 
thereby depriving the defendant of due process. ${ }^{27}$ There was no suggestion that the defendant, Dr. Sheppard, or his lawyer created publicity that prejudiced the prosecution. ${ }^{28}$ The proper scope of the Sheppard decision, therefore, is expressed in the following holding by the Court:

Due process requires that the accused receive a trial by an impartial jury free from outside influences. Given the pervasiveness of modern communications and the difficulty of effacing prejudicial publicity from the minds of the jurors, the trial courts must take strong measures to ensure that the balance is never weighed against the accused. ${ }^{29}$

Not only Sheppard but every other Supreme Court decision cited in the opinions in Nebraska Press Association involved publicity, often extremely severe, that was prejudicial to the accused; ${ }^{30}$ yet the Supreme Court upheld every conviction. ${ }^{31}$ As the Chief Justice summarized those cases in $\mathrm{Ne}$ braska Press Association, they demonstrate that pretrial publicity-"even pervasive, adverse publicity" against an accused-does not lead inevitably to a denial of due process. ${ }^{32}$

Furthermore, despite some ill-considered dicta $^{33}$ in cases involving publicity prejudicial to the accused, the Supreme Court has yet to confront a case in which pretrial publicity by the defendant has threatened irreparable prejudice to the prosecution's case. That is hardly surprising, of course, since "the scales of justice in the eyes of the public are weighed extraordinarily heavy against an accused after his indictment." 34 The presumption of innocence notwithstanding, the impact of an indictment upon the general public is so great that few defendants will be able to overcome it, much less turn it to their advantage.

27. Id. at 357,363 .

28. The Sheppard defense, however, did attempt to use the news media "to counter adverse publicity or to create a more favorable climate" for the defendant. ABA PROJECT ON MINIMUM STANDARDS FOR CRIMINAL JuSTICE, supra note 7, at 42-43. Given the posture of the case and the attitude of the press toward the defendant, such efforts were doomed to failure.

29. 384 U.S. at 362 (emphasis added).

30. See, e.g., Estes v. Texas, 38 I U.S. 532 (I965); Rideau v. Louisiana, 373 U.S. 723 (1963); Irvin v. Dowd, 366 U.S. 717 (1961).

3I. Murphy v. Florida, 421 U.S. 794 (I975) (extensive pretrial press coverage of the accused's arrest, alleged crime and prior felony convictions); Beck v. Washington, 369 U.S. $54 \mathrm{I}$ ( 1962 ) (extensive reporting on U.S. Senate investigation and grand jury indictment of the accused); Stroble v. California, 343 U.S. I8I (I95I) (petitioner described as a "werewolf," "fiend" and "sex-mad killer" in numerous press reports of his arrest for allegedly molesting and murdering a 6-year-old girl and of his confession to the crime).

32. $96 \mathrm{~S}$. Ct. at 2800 .

33. See, e.g. , Sheppard v. Maxwell, 384 U.S. 333, 36I (1966): "The fact that many of the prejudicial news items can be traced to the prosecution, as well as the defense, aggravates the judge's failure to take any action."

34. Chicago Council of Lawyers v. Bauer, 522 F.2d 242, 250 (7th Cir. 1975), cert. denied, 96 S. Ct. 320r (1976). 
A judicial process untainted by prejudice against the prosecution is certainly a worthy goal, but that is not the point so far as the Constitution is concerned. Rather, the point at the constitutional level is simply that no conflict exists between the defendant's right of free speech and possible trial prejudice to the government. ${ }^{35}$ The first amendment guarantees the former; nothing in the Constitution guarantees the latter. If balances are to be struck, therefore, the language of the first amendment unequivocally favors individual freedom of expression.

Although that conclusion may appear to be contradicted by some of the dicta in Nebraska Press Association, the ratio decidendi of the several opinions in that case clearly and powerfully support it. The Supreme Court recognized a "special protection" against prior restraints and a "heavy presumption" against their validity ${ }^{36}$ that is not reduced by the temporary nature of the restraint. ${ }^{37}$ Prior restraints, whether on "speech [or] publication," are "the most serious and least tolerable infringement on First Amendment rights." 38 Further, the Court stressed that "[a] responsible press has always been regarded as the handmaiden of effective judicial administration," serving to "[guard] against the miscarriage of justice by subjecting the police, prosecutors, and judicial process to extensive public scrutiny and criticism." 39

35. Moreover, no such conflict exists at the practical level. The fear that defendants will prejudice the prosecution by exercising freedom of speech is remote, if not fanciful. See note 34 supra and accompanying text.

36. $96 \mathrm{~S}$. Ct. at $280 \mathrm{I}-02$.

37. The Court also noted the practical problems inherent in framing and enforcing prior restraints and suggested less restrictive alternatives. "[A] court can anticipate only part of what will develop that may injure the accused." Id. at 2806 . As a result, the order may be underinclusive. Alternatively, an order that sought to cover all possible prejudicial publicity might well exceed the actual needs of the situation and restrict speech unduly. Instead, the Court suggested that the impact of prejudicial publicity can be mitigated, and perhaps even eliminated, by a change of venue, postponement of trial, searching voir dire, careful instructions to the jury, and sequestration of jurors. $I d$. at 2805 . Some defendants may prefer even to waive their right to a jury, rather than forego their right to freedom of speech. Most of these devices require defendants to waive basic constitutional rights in order to assure their right to a fair trial, a problem that becomes particularly acute when necessitated by prosecutorial misconduct. See note $6_{3}$ infra and accompanying text. However, the devices certainly should be made available to defendants as alternatives to enforced deprivation of free speech. Finally, Justice Brennan noted the prevalence of plea bargaining, which substantially reduces the likelihood of trial and likewise the necessity to impanel a jury. Id. at 2822 (Brennan, J., concurring). Justice Brennan cautioned, however, that in accepting such pleas, judges "must guard against the danger that pretrial publicity has effectively coerced the defendant into pleading guilty." Id. at 2822 n.24.

38. Id. at 2802 . "If it can be said that a threat of criminal or civil sanctions after publication 'chills' speech, prior restraint 'freezes' it . . . ." Id. at 2803 .

39. Id. at 2803, quoting Sheppard v. Maxwell, 384 U.S. 333, 350 (1966). Justice Brennan also expressed concern that "judges and committing magistrates might . . . be determining the propriety of publishing information that reflects on their competence, integrity or general performance on the bench," thereby exacerbating "the potential for arbitrary and excessive judicial 
In sum, the Court held that prior restraints not only infringe on a basic constitutional guarantee, but may be destructive of the very purpose they are intended to serve: the impartial administration of justice. In doing so, however, the Court focused only on the press as the subject of the restraint; it should have examined the effects on the defendant as well.

\section{The Constitutionality of Prior Restraints on the Parties to Criminal Proceedings}

\section{A. Restraints on the Defendant}

The foregoing arguments ${ }^{40}$ against prior restraint of the press militate at least as forcefully against prior restraints on the freedom of speech of defendants. But there are additional reasons why the Court should not approve orders restricting the first amendment rights of defendants and their attorneys. Both Chief Justice Burger and Justice Brennan emphasized the responsibility of the press to safeguard against miscarriages of justice. That function can be severely impaired, of course, if those who are most knowledgeable about injustices are silenced at the very moment at which they have the greatest incentive to protest. ${ }^{41}$

Indeed, circumstances will virtually never occur in which the right to freedom of speech could be of more importance to an individual than in the course of criminal proceedings. The prosecutor is privileged to publish to the world-including the defendant's family, friends, neighbors, and business associates-what in almost any other context would constitute libel per se. The indictment may contain detailed charges of the most heinous conduct, and the delay before ultimate vindication may be many months, if not years. ${ }^{42}$ In the meantime, entirely apart from the proceedings in court, the good name earned during a lifetime can be demolished. There can be no more pressing occasion, therefore, for immediate, effective, public rebuttal. ${ }^{43}$

utilization of any such power" and for "overemployment of the technique." $96 \mathrm{~S}$. Ct. at 2826 (Brennan, J., concurring).

40. See notes 36-39 supra and accompanying text.

4I. One court noted that "it is only when the litigation is pending and current news that the public's attention can be commanded." Chicago Council of Lawyers v. Bauer, 522 F.2d 242, 250 (7th Cir. 1975), cert, denied, 96 S. Ct. 3201 (1976).

42. For instance, the publicity surrounding the New York nursing home scandals and the resulting charges against Dr. Bernard Bergman prompted this remark from the federal judge who heard the case: "[I]t appears to be undisputed, that the media (and people desiring to be featured in the media) have vilified him for many kinds of evildoing of which he has in fact been innocent." United States v. Bergman, 416 F. Supp. 496, 502 (S.D.N.Y. 1976) (sentencing memorandum). The comment came 2 years after the attacks in the media began.

43. Cf. Royster, The Free Press and a Fair Trial, 43 N.C.L. Rev. 364,369 (1965):

"I . . . would shudder at the prospect of being charged with some crime, especially one 


\section{B. Restraints on the Defense Attorney}

The defense attorney's freedom of expression regarding pending litigation stems from two sources. The first is the defendant's right to respond publicly to the prosecutor's charges ${ }^{44}$ and the attorney's role as the defendant's champion against a "hostile world." 45 The second is the attorney's individual right to freedom of speech.

\section{The attorney as representative of the client.}

The attorney, as a professional advocate, is likely to be far more effective than the involved, unsophisticated and inarticulate client in presenting the latter's point of view. Indeed, clients may do serious damage to their causes if compelled to deal personally with the press. ${ }^{46}$ In reality, moreover, a defendant may not be given the opportunity to deal with the press. Defendants in highly publicized cases are often held without bail, ${ }^{47}$ or bail is set at a sum beyond their reach. In this situation, the defendant must rely on those "outside," and the logical choice to speak with the press will be the attorney.

Yet even lawyers fail to perceive the crucial role they play in this regard. The decision of the District of Columbia Bar to amend its disciplinary rule relating to trial publicity ironically illustrates the point. As promulgated by the American Bar Association, that provision restricts attorneygenerated trial publicity in civil cases and administrative proceedings as well as in criminal cases. In the District of Columbia, however, the rule was amended to eliminate the trial publicity restrictions but only in civil cases and in administrative proceedings. ${ }^{48}$ The ballot distributed to the Bar stated the reasons for the amendment:

of moral turpitude, and being condemned to suffer silence until some distant day when even an acquittal would not be recompense....

"It may not be so in theory, but in the real world there are policemen out to break all records in the number of arrests they can make. . . . There are prosecutors with the same failing. There are officers who in a tense situation yield to the temptation to arrest anyone for the sake of pacifying a public aroused by a murder or a rape. There have been spite arrests. There are, indeed, a hundred ways in which justice can be and sometimes is debauched by those whose job it is to serve it."

44. See United Transp. Union v. State Bar, 40 I U.S. 576 (197 I); United Mine Workers v. State Bar Ass'n, 389 U.S. 217, 222-23 (1967); Brotherhood of R.R. Trainmen v. Virginia ex rel. State Bar, 377 U.S. I, 6, 8 (1964); NAACP v. Button, 37 I U.S. 415, 440 (1963).

45. ABA Project on Standards for Criminal Justice, Standards Relating to the Prosecution Function AND the Defense FunCtion 145-46 (1971).

46. As Justice Brennan has observed, "[N]o one has suggested that confessions or statements against interest made by an accused to private individuals . . . would be inadmissible [at trial]." 96 S. Ct. at 2822 n.25 (Brennan, J., concurring).

47. Many states limit or prohibit bail for capital offenses. E.g., Ala. Code tit. I5, S 195 (1959); Cal. Penal Code $\$$ i 270 (West i970); Colo. Rev. Stat. \$ I6-4-1or (1973).

48. The amendment replaced DR 7-107(G) and (H) with Canon 20 of the old CANONS OF 
No question is raised about the provisions dealing with publicity in criminal proceedings. However, those dealing with civil and administrative proceedings obviously need more thought. In their present form they would bar an attorney's participation in preparing a client's press release responding to an FTC or SEC release alleging fraud. They would bar a labor union's attorney from participating in a press conference in which the union denied charges filed with the NLRB. They would prevent a lawyer from aiding a defendant in a libel action in describing the situation as he sees it. They would also bar a professional opinion about pending litigation given expressly for inclusion in a corporation's annual report. ${ }^{49}$

The extraordinary thing about that action by the Bar is its failure to recognize that the criminal defendant, no less than the defendant in a libel action, is entitled to a lawyer's assistance in publicly "describing the situation as he sees it." 50 Indeed, the administrative proceedings used to illustrate the reasons for the amendment are those most closely resembling criminal prosecution: charges filed against a union with the NLRB or charges of fraud by the FTC or SEC. Despite occasional suggestions that the first amendment provides broader freedom to public discussion of civil cases than of criminal cases, ${ }^{51}$ the Supreme Court has recognized that "the protection against prior restraint should have particular force as applied to reporting of criminal proceedings . . . ."52

Some critics suggest that the client should be compelled to forego professional assistance in communicating with the public because there may be "a very real conflict of interest between the defendant and his attorney in criminal cases" 53 because "that which enhances the prominence of the attorney may well result in prejudice to the client." 54 Justice Marshall effectively answered that contention by noting that the adversary

Professional ETHICs: "Newspaper publications by a lawyer as to pending or anticipared litigation may interfere with a fair trial in the Courts and otherwise prejudice the due administration of justice. Generally they are to be condemned. If the extreme circumstances of a particular case justify a statement to the public, it is unprofessional to make it anonymously. An ex parte reference to the facts should not go beyond quotation from the records and papers on file in court; but even in extreme cases it is better to avoid an ex parte statement." ABA CaNoNs OF PROFEsSIONAL ETHICs No. 20 (1968).

Although that canon condemns trial publicity in general terms, it has been more honored in the breach than in the observance, in both the Shakespearean and the modern colloquial meanings of the expression. See W. Shakespeare, Hamlet, Act I, Scene iv.

49. The ballot is quoted in M. FreEdman, LAWYERs' ETHICS IN AN Adversary SyStem 259 (1975).

50. Id.

51. See Chicago Council of Lawyers v. Bauer, 522 F.2d 242, 257-59 (7th Cir. 1975), cert. denied, 96 S. Ct. 3201 (1976).

52. Nebraska Press Ass'n v. Stuarr, 96 S. Ct. 2791, 2803 (1976).

53. ABA Project on Minimum Standards for CRiminal Justice, supra note $7, \$$ i. 1 commentary.

54. Id. 
system presumes "that an attorney will observe his responsibilities to the legal system, as well as to his client" and that no circumstances will “justify a court's limiting the attorney's opportunity to serve his client because of fear that he may disserve the system by violating accepted ethical standards." 55 For those seriously concerned about this alleged conflict of interest, surely there are less restrictive ways of dealing with the problem, including after-the-fact sanctions in the few relevant instances, rather than broad prior restraints that silence defendants in the face of public accusations of criminal conduct.

\section{The attorney as individual.}

In addition to the attorney's right to freedom of expression as the client's representative, "[1]awyers also enjoy first-class citizenship"56 and are entitled to freedom of expression in their own right. ${ }^{57}$ That freedom traditionally can be restricted only on the basis of some compelling state interest that takes precedence over it, an interest that will rarely, if ever, be present. ${ }^{58}$ In addition, for the attorney, just as for the defendant, the need to be able to speak freely about a specific case may be particularly acute. The attorney may be especially knowledgeable and concerned about aspects of needed law reform as illustrated by the client's case. ${ }^{59}$ In addition, the attorney will be knowledgeable about the specific case at issue and may feel particularly moved to speak out publicly about the injustices in that case. ${ }^{60}$ Finally, the attorney may be the subject of well-publicized personal attacks as a result of representing an unpopular client or cause and therefore may have an important personal stake in publicly setting the record straight. ${ }^{61}$

55. Geders v. United States, 425 U.S. 80 (1976) (Marshall, J., concurring); see cases cited in note 44 supra. ring).

56. Spevack v. Klein, 385 U.S. 511,516 ( 1967 ). See also id. at 520 (Fortas, J., concur-

57. Konigsberg v. State Bar, 353 U.S. 252, 273 (1957).

58. Sherbert v. Verner, 374 U.S. 398,406 (1963); NAACP v. Alabama ex rel. Patterson, 357 U.S. 449,463 (1958).

59. Moreover, at least insofar as trial publicity is consistent with the client's specific interests, the attorney has an affirmative professional obligation to urge improvements in the legal system. ABA CODE OF Professional Responsibility EC 8-i (1975). The Code goes so far as to suggest that the attorney should propose and support law reform "without regard to the general interests or desires of clients...." Id.

60. See, e.g., Why I Represented Dr. Bernard Bergman, Address by Monroe Freedman (September I, 1976)(on file with Stanford Law Review): "I came to find, as I got further and further into the case, that Dr. Bergman has been the victim of some of the most irresponsible and malicious character assassination that I have ever seen." See also note 42 supra.

6r. Id. In addition, note the charges against an attorney who sued in Gertz v. Robert Welch, Inc., 4 I 8 U.S. 323 (I974). 


\section{Restraints on the Prosecuting Attorney}

As an individual, the prosecuting attorney, too, has rights of freedom of speech protected by the first amendment. Moreover, as noted above, ${ }^{62}$ the prosecutor is specially privileged, as a result of his or her official status, to go beyond the bounds that normally restrict other citizens by publishing charges in an indictment that might otherwise constitute defamation. Thus, in at least one important respect, the prosecutor's rights of expression are broader than those of the ordinary citizen.

By the same token, however, prosecutors acting in their official governmental capacities ${ }^{63}$ may be forbidden to publish out-of-court attacks that might violate a defendant's fifth and sixth amendment rights to due process and a fair trial. That is, when the state, through its prosecutor, undertakes to deprive a person of life, liberty, or property, the state in the person of its prosecutor is limited by the requirements of due process of law.

Conceivably, the "less restrictive alternative" doctrine might apply to prosecutors as well as to defendants and their lawyers. However, consideration of the available alternatives suggests that the doctrine is inappropriate, at least when the prejudicial statements are made before the jury is selected and, therefore, before the jurors can be sequestered. Apart from sequestration, the most effective alternatives for avoiding the effects of prejudicial publicity are delaying the trial, changing venue and trying the case before a judge without a jury. Yet each of those alternatives involves the forfeiture by the defendant of a right guaranteed by the sixth amendment: the right to a speedy trial, the right to be tried in the state and district in which the crime was committed and the right to trial by jury. It is one thing to say that the defendant should be free to exercise his or her first amendment rights; if that should boomerang and result in so much prejudicial publicity that the defendant must waive one or more sixth amendment rights, so be it. ${ }^{64}$ But a state, through its prosecutors, may not create prejudicial pretrial publicity that compels the defendant to

62. See text accompanying note 42 supra.

63. Cf. M. FreedMan, supra note 49 , at 79-80.

64. Similarly, the accused might justify a public response by the prosecutor (which otherwise would be improper) by making direct personal attacks upon the prosecutor, such as alleging that the prosecutor is corrupt or politically motivated in the case. Compare, however, Chicago Council of Lawyers v. Bauer, 522 F.2d 242, 253 (7th Cir. 1975) cert. denied, 96 S. Ct. 320 I (1976): "Admittedly, our formulation may place prosecutors in a difficult position since they may be criticized for a particular investigation but may not publicly respond. This is a situation that compering interests necessitate. Ultimately the prosecutor's response will come in the form of an indictment or information or else the investigation will have ended and his speech will be unrestricted." 
forfeit other basic rights under the sixth amendment in an effort to avoid the full impact of the damaging publicity.

\section{CONCLUSION}

Both the majority opinion and the principal concurring opinion in Nebraska Press Association marshal a number of compelling reasons for reaffirming the first amendment's guarantee of freedom of the press against contentions that the sixth amendment right to a fair trial justifies the use of prior restraints. The Court stressed the role of the press as "the handmaiden of effective judicial administration,"65 subjecting police, prosecutors and judges to public scrutiny and criticism. That role might be severely compromised if judges possessed the means of preventing criticism of their own performance on the bench. On a more practical level, the Court noted the possibility of less restrictive alternatives and the difficulty of framing a prior restraint order properly tailored to the problem at hand. ${ }^{66}$

Those overwhelming arguments against prior restraints of the press apply with equal force to prior restraints against defendants and their attorneys, whose rights of free speech are also explicitly guaranteed by the first amendment. Moreover, the original justification - the fear of prejudicial publicity-simply does not exist with respect to defendants and their lawyers. The sixth amendment guarantees a fair trial to the defendant, not to the state, and the defendant's exercise of first amendment rights poses no threat to that guarantee. ${ }^{67}$ More importantly, the accused has a first amendment right to reply publicly to the prosecutor's charges, and the public has a right to hear that reply, because of its ongoing concern for the integrity of the criminal justice system and the need to hear from those most directly affected by it.

The irony of Nebraska Press Association is that the opinions recognize so clearly the infirmities of prior restraints against the press but suggest as a possible "less restrictive alternative" that trial courts might impose prior restraints upon defendants and their attorneys. Perhaps because the issue was not argued or because the problem of prior restraints traditionally has been framed in terms of the press rather than individuals, the Court overlooked the ready applicability of its arguments against prior restraints to situations involving the first amendment rights of defendants. For whatever reason, the Court appears to have adopted Justice Stewart's distinction between the first amendment rights of individuals and those of

65. Nebraska Press Ass'n v. Stuart, 96 S. Ct. 2791, 2803 (1976), quoting Sheppard v. Maxwell, 384 U.S. 333,350 (1966). See note 39 supra and accompanying text.

66. See note 37 supra.

67. See note 4 supra and accompanying text. 
the press, ${ }^{68}$ an argument it apparently rejected in Pell v. Procunier. ${ }^{69}$ Yet the adoption, if such it was, came too easily, in marked contrast to the careful consideration given the other issues in Nebraska Press Association.

Future litigation in this area necessarily will focus upon the conflict between the Court's ill-considered obiter dicta and the carefully reasoned ratio decidendi of the two principal opinions in the Nebraska Press Association case. Yet the conflict is a superficial one, and the compelling analysis underlying Nebraska Press Association will require at least the same heavy presumption against prior restraints on the first amendment rights of defendants and their attorneys as has been recognized with respect to orders limiting press reports of pending litigation.

68. Or of the Press, Address by Justice Stewart, Yale Law School Sesquicentennial Convocation (Nov. 2, 1974), excerpted at 26 HASTINGs L.J. 63I, 633-35 (1975).

69. 417 U.S. $817,833-34$ (1974). 
